\title{
Biodiversity loss in the genus Artemia in the Western Mediterranean Region
}

\author{
Francisco Amat ${ }^{1, *}$, Francisco Hontoria ${ }^{1}$, Juan Carlos Navarro ${ }^{1}$, Natividade Vieira ${ }^{2}$ and \\ Graziella Mura ${ }^{3}$ \\ 1 Instituto de Acuicultura de Torre de la Sal (IATS - CSIC). 12595 Ribera de Cabanes (Castellón). España. \\ 2 Departamento de Zoología e Antropología. Faculdade de Ciencias. Universidad de Porto. 4099-002 Porto (Portugal). \\ 3 Dipartimento di Biología Animale e dell’Uomo, Università La Sapienza, Viale Dell’Università 32, 00185 Roma (Italia). \\ * Corresponding author: amat@iats.csic.es
}

\begin{abstract}
Biodiversity loss in the genus Artemia in the Western Mediterranean Region

Local populations extinctions depend on intrinsic factors related to the biology of species, as well as on direct threats of stochastic and/or deterministic type. The species of the genus Artemia (Branchiopoda, Anostraca), conspicuous inhabitants of hypersaline ecosystems, are suffering an important biodiversity loss. Their persistence is dramatically affected by deterministic factors threatening their biotopes. Among these deterministic factors the loss of habitats and the introduction of exotic invasive species are the most relevant. This paper aims to summarize the information available on: a) the abandonment of solar salterns in the Western Mediterranean region; b) the present distribution of the exotic invasive species Artemia franciscana populations in Spain, Portugal, Italy and France; c) several reproductive parameters obtained from the study of life tables, performed for several autochthonous species and strains and the invasive species. These traits, linked to the quantitative and qualitative offspring output, allow an experimental approach to the understanding of the fitness superiority of the invasive species, as well as to the competitive displacement of the autochthonous Artemia species in the Western Mediterranean region.
\end{abstract}

Key words: Artemia, loss of habitats, invasive species, fitness, competition, displacement, Western Mediterranean.

\section{RESUMEN}

Pérdida de biodiversidad en el género Artemia en la región del Mediterraneo Occidental

La extinción de poblaciones locales depende de factores intrínsecos que tienen que ver con la biología de las especies, así como de amenazas directas de tipo estocástico o determinístico. Las especies del género Artemia (Branchiopoda, Anostraca), conspicuos pobladores de humedales hipersalinos, están sufriendo una importante pérdida en biodiversidad. Su persistencia se ve dramáticamente afectada por factores determinísticos que amenazan a sus biotopos. De entre estos factores, la pérdida de hábitats y la introducción de especies exóticas invasoras son los más relevantes. Este trabajo pretende resumir la información disponible sobre: a) el abandono de salinas solares en la región del Mediterráneo Occidental; b) la distribución actual de poblaciones de la especie exótica invasora Artemia franciscana en España, Portugal, Italia y Francia; c) varios parámetros reproductivos obtenidos del estudio de tablas de vida, llevadas a cabo para varias especies y estirpes autóctonas y la especie invasora. Estos aspectos cuantitativos y cualitativos de la descendencia permiten una aproximación experimental a la comprensión de la superior eficacia biológica de la especie invasora, así como del desplazamiento por competencia de las especies autóctonasde Artemia en la región del Mediterráneo Occidental.

Palabras clave: Artemia, pérdida de hábitats, especies invasoras, eficacia biológica, competencia, desplazamiento, Mediterráneo Occidental. 


\section{INTRODUCTION}

The impact of invasive species on the ecosystems, communities and native species is known since several decades ago (Elton, 1958; Lodge, 1993; Simberloff, 1996). The level of knowledge and understanding of the mechanisms leading to the success of the invasive is far to provide neither criteria to predict the threat of invasions nor how to act or to manage ecosystems already invaded. The understanding of invasive mechanisms compel to an exhaustive comprehension of the interactions triggered between the exotic and the native species, since their fate becomes always rather more complex (Wooton, 1994; Grosholz \& Ruiz, 1996; Byers, 2000).

Invasion success and impacts depend on the competitive and trophic interactions to arise in the environment where invasive and analog native species meet, but the knowledge of these interactions is only possible when the invasion has already happened. If the exotic species behaves openly as invasive, the prospects ahead are probably irreversible (Herbold \& Moyle, 1986). The research on invasive species offers singular opportunities for the understanding of population's biology, due to the evidence that their evolution proceeds faster than usual in natural environments (Sakai et al., 2001).

The introduction of exotic invasive species where congeneric native species exist leads to the extinction of the latter in the long term. Invasions and the loss of fit environments for the development of autochthonous species are in the basis of the global biodiversity damage. Biodiversity, a dynamic process shaped by time and the interaction of natural processes, biotic and abiotic, is threatened by the present globalization phenomenon, together with alien species introduction, hybridizations, displacements and extinctions of autochthonous species (Sakai et al., 2001; Mooney \& Cleland, 2001; Jiménez Pérez, 2005).

Aquatic ecosystems are also suffering from these impacts markedly. Freshwater or continental environments, like the Ebro River that shows the presence of zebra mussel (Dreissena polymorpha), or the marine habitats displaying macroalgae invasions, like Caulerpa taxifolia in the Western
Mediterranean, serve as examples in our latitudes. Hypersaline aquatic environments, like coastal and epicontinental lagoons or exploited solar salterns, characterized by a high productivity and low diversity, are not free of these impacts. In these environments, one of their most conspicuous inhabitant, the brine shrimp Artemia, is probably the most dangerously threatened.

The genus Artemia comprises a group of six bisexual species and a variety of parthenogenetic strains of diverse ploidy. Two of these bisexual species are autochthonous from America. Artemia franciscana is probably the most abundant, spread all around the American continent (Vanhaecke et al., 1987; Hontoria \& Amat, 1992b; Triantaphyllidis et al., 1998; Abatzopoulos et al., 2002). In the American South Cone A. persimilis is nearly exclusive (Cohen et al., 1999; Amat et al., 2004; Gajardo et al., 2004) . In the Mediterranean basin a bisexual species A. salina occurs together with two parthenogenetic strains, one diploid and another tetraploid. Several taxa may occur in simpatry, developing concurrently or seasonally overlapping populations along the year (Amat, 1983; Lenz \& Browne, 1991; Hontoria \& Amat, 1992a; Amat et al., 1995). These strains became common in all the countries of the Mediterranean area, in Southern Europe, as well as in North Africa, in accordance to their phenotypic plasticity and the fitness traits of their life history, determined by climatic parameters inherent to their conspicuously changing hypersaline environments (Abatzopoulos et al., 2002) The other Old World species are distributed in Asia, with the exclusive presence of $A$. urmiana in lake Urmia (Iran), A. sinica in China and neighboring areas, and A. tibetiana present in salt lakes of the Tibetan plateau. Parthenogenetic strains, mainly diploid, are also abundant in Asia, coexisting or not with the bisexuals.

The biodiversity of Artemia populations in the Mediterranean basin has suffered a great change after the first recording of $A$. franciscana specimens. This event was initially stated in Portugal (Hontoria et al., 1987) and later in France (Thiery \& Robert, 1992). Recent reports demonstrate this invasion in Spain and Morocco (Amat et al., 2005; Green et al., 2005). Today the 
invasive species is present in the Italian salterns from Margherita di Savoia (Mura et al., 2004), and just recorded in La Trinidad salterns (Alfaques Bay, Tarragona, Spain) as described in this work.

Several attributes of biological fitness characterizing invasive species are known after data from Ehrlich (1984), Lodge (1993), Shigesada \& Kawasaki (1997) and McMahon (2002). However, their invasive potential becomes evident when fitness mechanisms are associated with human activities enabling their arrival or introduction to new ecosystems. In the case of Artemia, the important role played by this crustacean in the development of salt exploitation in big industrial solar salterns, or in the modern marine aquacultural technologies, likely provoked the initial introductions of $A$. franciscana evidencing its status of exotic and invasive species.

Once acknowledged the important threats on biodiversity defined by some deterministic factors (Jiménez Pérez, 2005) like the introduction of exotic invasive species and the fragmentation or loss of habitats, and by some stochastic factors, basically demographic, bound to biological fitness, this work aims to a) summarize the loss of hypersaline environments essential for Artemia populations, mainly focusing on solar salterns abandonment in the Western Mediterranean region during the last decades, b) the identification of new invasive Artemia franciscana populations appeared since Amat et al., (2004) and c) compare reproductive parameters for some autochthonous and invasive Artemia strains developed in the laboratory under static conditions.

\section{MATERIALS AND METHODS}

\section{Biotope loss}

The assessment of the status of hypersaline biotopes was possible through different tools: bibliographic data recopilation, in situ prospections and Artemia cysts sampling, including some

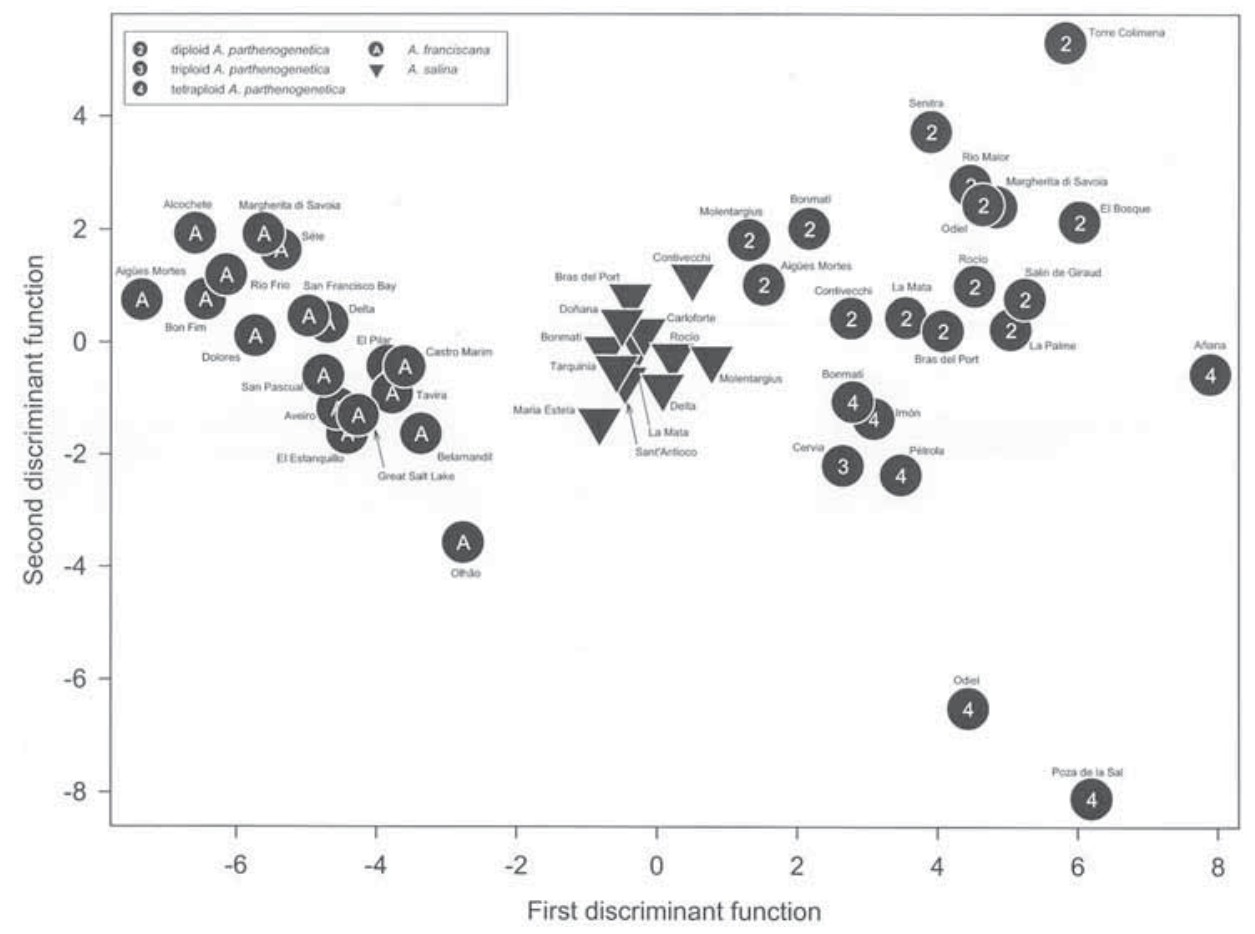

Figure 1. Group centroids of the populations studied for the first two discriminant functions resulting from the discriminant analysis on female morphometric variables. Grupo de centroides obtenidos para las poblaciones estudiadas a partir de las dos primeras funciones del análisis discriminante aplicado a las variables morfométricas de los especímenes hembras. 


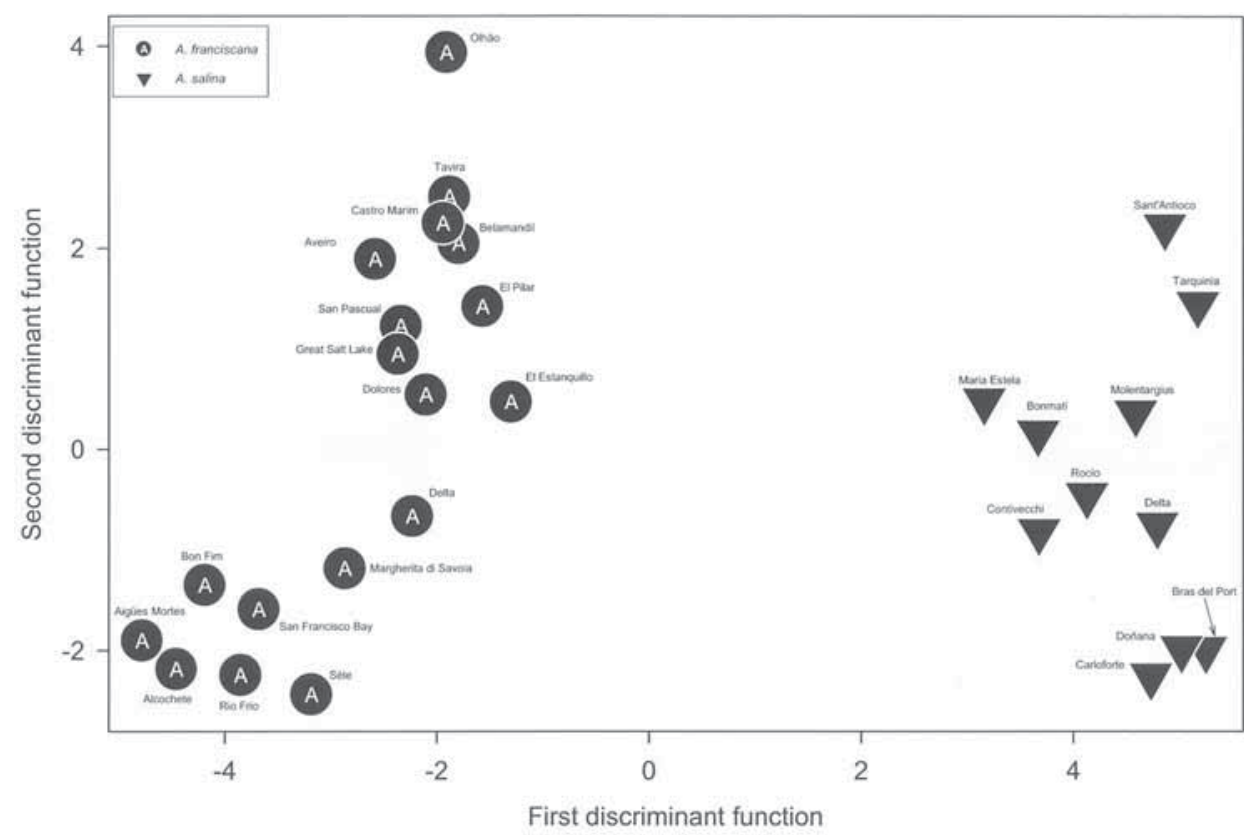

Figure 2. Group centroids of the populations studied for the first two discriminant functions resulting from the discriminant analysis on male morphometric variables. Grupo de centroides obtenidos para las poblaciones estudiadas a partir de las dos primeras funciones del análisis discriminante aplicado a las variables morfométricas de los especímenes machos.

cyst samples obtained from studies of Artemia dispersal by waterbirds (Green et al., 2005).

Many departmental (autonomic) government administrations and cultural foundations in Spain, aware of the importance of salt exploitations as cultural, ethnographic, historical and economic heritage, have developed important inventories of these settlements, reporting on their status of activity. This information was fully available from the environmental departments of Junta de Andalucía (Pérez Hurtado de Mendoza, 2004), Cabildo Insular de Lanzarote in the Canary Islands (Marín and Luengo, 1994), and from Fundació "Sa Nostra" in the Balearic Islands (Frontera, 2005).

Previous engagements arisen from a former INCO-EU project on Artemia biodiversity at global scale, together with several international projects (Concerted Actions) among Spain (Instituto de Acuicultura de Torre de la Sal), Portugal (University of Porto), Italy (University of Rome) and Greece (University of Thessalonica) allowed the prospection of Portuguese and Italian salterns during 2004-2005.

Finally, previous and in progress collabora- tions with the "Estación Biológica de Doñana (CSIC)" and the University of Cadiz in Spain, allowed to verify the presence of formerly known autochthonous Artemia populations and/or the lately introduction of the exotic invasive A. franciscana (Amat et al., 1995; Green et al., 2005).

The information provided by literature (period 1994-2005) for Spain, and that obtained after the different prospective and sampling campaigns (2004-2005) for Portugal and Italy, was compiled and compared with the information previously available for the region (Amat et al., 2005).

\section{Invasion extent}

The Artemia populations studied for the first time and the populations with modified species composition since Amat et al., (2005) are listed in Table 1 (A). These populations were obtained from cyst samples collected in the prospections developed during the period 2004-2006. The populations already cited in Amat et al., (2005), with species composition unchanged, are listed in Table 1 (B).

Part of the information presented in Amat et 
Table 1. List of populations studied for the first time and other populations with updated status since Amat et al.,(2005) (A), and those with status unchanged and already cited in this report (B).Geographical coordinates and Artemia species and strains are given: AS, Artemia salina; AF, Artemia franciscana; PD, diploid; PI, triploid; PT, tetraploid parthenogenetic strains. Lista de las poblaciones estudiadas por primera vez y de aquellas cuya composición ha sido actualizada a partir de Amat et al., (2005) (A), y de las que no han sufrido ningún cambio posterior (B). Se especifican las coordenadas geográficas y las especies o cepas de Artemia halladas: AS, Artemia salina; AF, Artemia franciscana; PD, PI, PT, cepas partenogenéticas diploide, triploide y tetraploide.

\begin{tabular}{|c|c|c|c|}
\hline & Origin & Geographical coordinates & Species or strain \\
\hline \multicolumn{4}{|c|}{ A. Populations studied for the first time and other populations with updated status (Amat et al., 2005). } \\
\hline \multicolumn{4}{|c|}{ PORTUGAL } \\
\hline \multicolumn{4}{|l|}{ Algarve District } \\
\hline Castro Marim (MarVaz Saltern) & $37^{\circ} 13^{\prime} 4^{\prime \prime} \mathrm{N}$ & $7^{\circ} 26^{\prime} 16^{\prime \prime} \mathrm{W}$ & $\mathrm{AF}$ \\
\hline Tavira (Santa Luzia Saltern) & $37^{\circ} 6^{\prime} 25^{\prime \prime} \mathrm{N}$ & $7^{\circ} 38^{\prime} 38^{\prime \prime} \mathrm{W}$ & $\mathrm{AF}$ \\
\hline Olhão (Belamandil Saltern) & $37^{\circ} 1^{\prime} 27^{\prime \prime} \mathrm{N}$ & $7^{\circ} 52^{\prime} 3^{\prime \prime} \mathrm{W}$ & $\mathrm{AF}$ \\
\hline \multicolumn{4}{|l|}{ Tagus Estuary } \\
\hline Alcochete (Marinha Brito Saltern) & $38^{\circ} 44^{\prime} 44^{\prime \prime} \mathrm{N}$ & $8^{\circ} 58^{\prime} 37^{\prime \prime} \mathrm{W}$ & $\mathrm{AF}$ \\
\hline Rio Maior Salterns & $39^{\circ} 21^{\prime} 47^{\prime \prime} \mathrm{N}$ & $8^{\circ} 56^{\prime} 33^{\prime \prime} \mathrm{W}$ & PD \\
\hline \multicolumn{4}{|l|}{ Aveiro District } \\
\hline Aveiro (Senitra Saltern) & $40^{\circ} 38^{\prime} 37^{\prime \prime} \mathrm{N}$ & $8^{\circ} 39^{\prime} 57^{\prime \prime} \mathrm{W}$ & PD \\
\hline \multicolumn{4}{|l|}{ ITALY } \\
\hline \multicolumn{4}{|l|}{ Apulia Province } \\
\hline Margherita di Savoia Salterns & $41^{\circ} 22^{\prime} 59^{\prime \prime} \mathrm{N}$ & $16^{\circ} 5^{\prime} 20^{\prime \prime} \mathrm{E}$ & AF, PD \\
\hline Torrecolimena Saltern & $40^{\circ} 18^{\prime} 7^{\prime \prime} \mathrm{N}$ & $17^{\circ} 43^{\prime} 55^{\prime \prime} \mathrm{E}$ & PD \\
\hline Cervia Saltern & $44^{\circ} 15^{\prime} 3^{\prime \prime} \mathrm{N}$ & $12^{\circ} 20^{\prime} 17^{\prime \prime} \mathrm{E}$ & PI \\
\hline \multicolumn{4}{|l|}{ Sardinia } \\
\hline Cagliari (Contivecchi Salterns) & $39^{\circ} 13^{\prime} 49^{\prime \prime} \mathrm{N}$ & $9^{\circ} 2^{\prime} 0^{\prime \prime} \mathrm{E}$ & AS, PD \\
\hline Cagliari (Molentargius Salterns) & $39^{\circ} 13^{\prime} 43^{\prime \prime} \mathrm{N}$ & $9^{\circ} 12^{\prime} 25^{\prime \prime} \mathrm{E}$ & AS, PD \\
\hline Sant'Antioco Salterns & $39^{\circ} 3^{\prime} 53^{\prime \prime} \mathrm{N}$ & $8^{\circ} 32^{\prime} 27^{\prime \prime} \mathrm{E}$ & AS \\
\hline \multicolumn{4}{|l|}{ Sicily (Trapani) } \\
\hline Trapani (Maria Stella Salterns) & $37^{\circ} 59^{\prime} 35^{\prime \prime} \mathrm{N}$ & $12^{\circ} 32^{\prime} 8^{\prime \prime} \mathrm{E}$ & AS \\
\hline \multicolumn{4}{|l|}{ FRANCE } \\
\hline \multicolumn{4}{|l|}{ Languedoc-Roussillon } \\
\hline La Palme-Sigean Salterns & $42^{\circ} 58^{\prime} 30^{\prime \prime} \mathrm{N}$ & $3^{\circ} 1^{\prime} 33^{\prime \prime} \mathrm{E}$ & PD \\
\hline \multicolumn{4}{|l|}{ Provence } \\
\hline Salin de Giraud Salterns & $43^{\circ} 30^{\prime} 52^{\prime \prime} \mathrm{N}$ & $4^{\circ} 35^{\prime} 56^{\prime \prime} \mathrm{E}$ & PD \\
\hline \multicolumn{4}{|l|}{ SPAIN } \\
\hline \multicolumn{4}{|l|}{ Cádiz Province } \\
\hline Puerto de Santa María (La Tapa Saltern) & $36^{\circ} 35^{\prime} 52^{\prime \prime} \mathrm{N}$ & $6^{\circ} 13^{\prime} 7^{\prime \prime} \mathrm{W}$ & $\mathrm{AF}$ \\
\hline Prado del Rey (El Bosque Saltern) & $36^{\circ} 47^{\prime} 12^{\prime \prime} \mathrm{N}$ & $5^{\circ} 33^{\prime} 24^{\prime \prime} \mathrm{W}$ & PD \\
\hline \multicolumn{4}{|l|}{ Tarragona Province } \\
\hline Ebro River Delta (La Trinidad Saltern) & $40^{\circ} 34^{\prime} 58^{\prime \prime} \mathrm{N}$ & $0^{\circ} 40^{\prime} 49^{\prime \prime} \mathrm{E}$ & AF, AS \\
\hline \multicolumn{4}{|l|}{ Burgos Province } \\
\hline Poza de la Sal Salterns & $42^{\circ} 40^{\prime} 6^{\prime \prime} \mathrm{N}$ & $3^{\circ} 30^{\prime} 0^{\prime \prime} \mathrm{W}$ & PT \\
\hline \multicolumn{4}{|l|}{ Guadalajara Province } \\
\hline Imón Salterns & $41^{\circ} 9^{\prime} 33^{\prime \prime} \mathrm{N}$ & $2^{\circ} 43^{\prime} 39^{\prime \prime} \mathrm{W}$ & PT \\
\hline \multicolumn{4}{|l|}{ Huelva Province } \\
\hline Doñana National Park (San Isidro Salterns) & $36^{\circ} 52^{\prime} 43^{\prime \prime} \mathrm{N}$ & $6^{\circ} 21^{\prime} 24^{\prime \prime} \mathrm{W}$ & AS \\
\hline \multicolumn{4}{|l|}{ Alicante Province } \\
\hline Santa Pola (Bras del Port Salterns) & $38^{\circ} 11^{\prime} 21^{\prime \prime} \mathrm{N}$ & $0^{\circ} 36^{\prime} 21^{\prime \prime} \mathrm{W}$ & AS, PD \\
\hline Santa Pola (Bonmatí Salterns) & $38^{\circ} 10^{\prime} 5^{\prime \prime} \mathrm{N}$ & $0^{\circ} 37^{\prime} 21^{\prime \prime} \mathrm{W}$ & AS, PD, PT \\
\hline
\end{tabular}


Table 1. cont.

\begin{tabular}{|c|c|c|c|}
\hline & Origin & Geographical coordinates & Species or strain \\
\hline \multicolumn{4}{|c|}{ B. Populations already cited in Amat et al. (2005) with status unchanged. } \\
\hline \multicolumn{4}{|l|}{ PORTUGAL } \\
\hline \multicolumn{4}{|l|}{ Algarve District } \\
\hline Olhão Salterns & $37^{\circ} 1^{\prime} 27^{\prime \prime} \mathrm{N}$ & $7^{\circ} 51^{\prime} 21^{\prime \prime} \mathrm{W}$ & $\mathrm{AF}$ \\
\hline \multicolumn{4}{|l|}{ Sado Estuary } \\
\hline Bom Fim Salterns & $38^{\circ} 24^{\prime} 21^{\prime \prime} \mathrm{N}$ & $8^{\circ} 34^{\prime} 36^{\prime \prime} \mathrm{W}$ & $\mathrm{AF}$ \\
\hline Rio Frio Salterns & $38^{\circ} 24^{\prime} 21^{\prime \prime} \mathrm{N}$ & $8^{\circ} 34^{\prime} 36^{\prime \prime} \mathrm{W}$ & $\mathrm{AF}$ \\
\hline \multicolumn{4}{|l|}{ Aveiro District } \\
\hline Aveiro (Esmolas Saltern) & $40^{\circ} 39^{\prime} 25^{\prime \prime} \mathrm{N}$ & $8^{\circ} 41^{\prime} 26^{\prime \prime} \mathrm{W}$ & $\mathrm{AF}$ \\
\hline \multicolumn{4}{|l|}{ ITALY } \\
\hline \multicolumn{4}{|l|}{ Lazio Province } \\
\hline Tarquinia Salterns & $41^{\circ} 18^{\prime} 34^{\prime \prime} \mathrm{N}$ & $13^{\circ} 20^{\prime} 44^{\prime \prime} \mathrm{E}$ & AS \\
\hline \multicolumn{4}{|l|}{ Sardinia } \\
\hline Carloforte Salterns & $39^{\circ} 7^{\prime} 59^{\prime \prime} \mathrm{N}$ & $8^{\circ} 18^{\prime} 13^{\prime \prime} \mathrm{E}$ & AS \\
\hline \multicolumn{4}{|l|}{ FRANCE } \\
\hline \multicolumn{4}{|l|}{ Languedoc-Roussillon } \\
\hline Aigües Mortes Salterns & $43^{\circ} 33^{\prime} 58^{\prime \prime} \mathrm{N}$ & $4^{\circ} 11^{\prime} 28^{\prime \prime} \mathrm{E}$ & AF, PD \\
\hline Sète Salterns & $43^{\circ} 23^{\prime} 1^{\prime \prime} \mathrm{N}$ & $3^{\circ} 37^{\prime} 59^{\prime \prime} \mathrm{E}$ & $\mathrm{AF}$ \\
\hline \multicolumn{4}{|l|}{ SPAIN } \\
\hline \multicolumn{4}{|l|}{ Cádiz Province } \\
\hline Sanlúcar (Rocío Saltern) & $36^{\circ} 52^{\prime} 39^{\prime \prime} \mathrm{N}$ & $6^{\circ} 19^{\prime} 47^{\prime \prime} \mathrm{W}$ & AS, PD \\
\hline San Fernando (El Estanquillo Saltern) & $36^{\circ} 25^{\prime} 53^{\prime \prime} \mathrm{N}$ & $6^{\circ} 12^{\prime} 58^{\prime \prime} \mathrm{W}$ & $\mathrm{AF}$ \\
\hline San Fernando (El Pilar Saltern) & $36^{\circ} 29^{\prime} 11^{\prime \prime} \mathrm{N}$ & $6^{\circ} 9^{\prime} 57^{\prime \prime} \mathrm{W}$ & $\mathrm{AF}$ \\
\hline Puerto Real (Dolores Saltern) & $36^{\circ} 30^{\prime} 47^{\prime \prime} \mathrm{N}$ & $6^{\circ} 9^{\prime} 40^{\prime \prime} \mathrm{W}$ & $\mathrm{AF}$ \\
\hline Puerto Real (San Pascual Saltern) & $36^{\circ} 30^{\prime} 47^{\prime \prime} \mathrm{N}$ & $6^{\circ} 9^{\prime} 40^{\prime \prime} \mathrm{W}$ & $\mathrm{AF}$ \\
\hline \multicolumn{4}{|l|}{ Huelva Province } \\
\hline Odiel River Salterns & $37^{\circ} 15^{\prime} 1^{\prime \prime} \mathrm{N}$ & $6^{\circ} 59^{\prime} 26^{\prime \prime} \mathrm{W}$ & $\mathrm{PD}, \mathrm{PT}$ \\
\hline $\begin{array}{l}\text { Tarragona Province } \\
\text { Ebro River Delta (La Trinidad Saltern) }\end{array}$ & $40^{\circ} 34^{\prime} 58^{\prime \prime} \mathrm{N}$ & $0^{\circ} 40^{\prime} 49^{\prime \prime} \mathrm{E}$ & PT \\
\hline \multicolumn{4}{|l|}{ Alicante Province } \\
\hline Torrevieja (La Mata Lagoon) & $38^{\circ} 2^{\prime} 8^{\prime \prime} \mathrm{N}$ & $0^{\circ} 42^{\prime} 30^{\prime \prime} \mathrm{W}$ & $\mathrm{AS}, \mathrm{PD}$ \\
\hline \multicolumn{4}{|l|}{ Murcia Province } \\
\hline San Pedro del Pinatar Salterns & $37^{\circ} 49^{\prime} 0^{\prime \prime} \mathrm{N}$ & $0^{\circ} 46^{\prime} 0^{\prime \prime} \mathrm{W}$ & AS \\
\hline \multicolumn{4}{|l|}{ Alava Province } \\
\hline Añana Salterns & $42^{\circ} 48^{\prime} 2^{\prime \prime} \mathrm{N}$ & $2^{\circ} 59^{\prime} 8^{\prime \prime} \mathrm{W}$ & PT \\
\hline \multicolumn{4}{|l|}{ Albacete Province } \\
\hline Pétrola Salterns & $38^{\circ} 50^{\prime} 0^{\prime \prime} \mathrm{N}$ & $1^{\circ} 33^{\prime} 34^{\prime \prime} \mathrm{W}$ & PT \\
\hline \multicolumn{4}{|l|}{ MOROCCO } \\
\hline \multicolumn{4}{|l|}{ El Jadida District } \\
\hline Oualidia (Salines Marocaines) & $32^{\circ} 44^{\prime} 50^{\prime \prime} \mathrm{N}$ & $9^{\circ} 1^{\prime} 39^{\prime \prime} \mathrm{W}$ & AS \\
\hline \multicolumn{4}{|l|}{ U.S.A. (A. franciscana reference) } \\
\hline \multicolumn{4}{|l|}{ California } \\
\hline San Francisco Bay & $37^{\circ} 30^{\prime} 11^{\prime \prime} \mathrm{N}$ & $122^{\circ} 12^{\prime} 11^{\prime \prime} \mathrm{W}$ & $\mathrm{AF}$ \\
\hline \multicolumn{4}{|l|}{ Utah } \\
\hline Great Salt Lake & $40^{\circ} 57^{\prime} 51^{\prime \prime} \mathrm{N}$ & $112^{\circ} 20^{\prime} 51^{\prime \prime} \mathrm{W}$ & $\mathrm{AF}$ \\
\hline
\end{tabular}


al., (2005) was inferred from the cyst biometry of the samples that had lost their hatching capability. This species identification method is much less precise than the adult morphology analysis. For this reason, in the present study samples of cysts obtained in the same geographical localities, but in recent collections (2004-2005), as well as those collected in other places, have been used. These samples have been hatched successfully, thus obtaining adult populations after nauplii rearing in standardized conditions. This has allowed its morphometric study through discriminant analysis and, consequently, a complete and precise species identification of all the populations studied. The detailed study of the morphology is the fastest way to ascertain the adscription of a population of Artemia to the species to which it belongs. This is due to the similarity of the morphology among the different Artemia species, that are considered "sibling" species.

The samples of Artemia cysts were cleaned and treated in all cases with standardized methods (Vanhaecke \& Sorgeloos, 1980) and included in the cyst bank maintained in the IATS. Batches of nauplii were hatched from these cysts after their incubation in sea water (salinity $35 \mathrm{gL}^{-1}$, temperature $28^{\circ} \mathrm{C}$, continuous light, and aeration by air bubbling). These nauplii were grown in a culture medium made of a mixture of the microalgae Dunaliella salina and Tetraselmis suecica, maintained at salinity $70 \mathrm{gL}^{-1}, 24 \pm 1^{\circ} \mathrm{C}$ temperature, and 12:12 h light/darkness regime. Complete medium renewal was performed every 2-3 days.

The cultures were maintained in these conditions until $50 \%$ of the females in a batch showed the ovisac developed with their first brood. At this moment a visual identification of the specimens was carried out under binocular microscope. This allowed ascertaining whether the original population was pure or a mixture of several strains. After this previous selection, a multivariate discriminant analysis on the morphometric characters was performed to confirm the systematic adscription of the sample individuals. Samples of 30 females (in parthenogenetic populations as well as in the bisexuals) and 30 males (bisexual populations) were randomly taken, anesthetized, and the morphome- tric traits of their specimens measured under a binocular microscope equiped with a micrometric eyepiece. The morphological traits and the data processing details are extensively explained in Hontoria \& Amat (1992a). The statistic package SPSS for Windows 13.0 (SPSS Inc., Chicago, Illinois, U.S.A.) was used for all the computations. The data were added to the morphological database maintained in the IATS.

\section{Life tables}

Eight Artemia populations were chosen for this study, with two representatives for every species or strain (Table 1): San Pedro del Pinatar (Spain) and Salines Marocaines (Morocco) for the bisexual A. salina; Margherita di Savoia (Italy) and Ebro River Delta (Spain) for the bisexual invasive $A$. franciscana; Rio Maior (Portugal) and Margherita di Savoia (Italy) for the diploid parthenogenetic, and Imón (Spain) and Ebro River Delta (Spain) for the tetraploid parthenogenetic.

Three to five batches of 30 nauplii from every population were isolated into $50 \mathrm{~mL}$ container aliquots. Culture medium conditions described above were provided to these nauplii. They were monitored every 2 to 3 days to renew completely the medium and to evaluate the survival. When young females showed ovulation, previously to the first brood, they were isolated, individually (parthenogenetic) or with a male (bisexuals), in $50 \mathrm{~mL}$ containers under the same culture conditions. Monitoring of the life span and reproduction, and culture medium renewal, were performed every two-three days. Dead males in bisexual matings were replaced from mass culture containers kept under the same conditions. Life table parameters monitored were the length of prereproductive (time to attain the first brood), the reproductive (time of active reproduction from the first to the last broods), and the postreproductive (time elapsed between the last brood and death) periods. The mean time elapsed between broods and the total life span, in days, were followed. In addition, the total number of broods per female, and the total offspring per female, per brood and per day, were also monitored. Finally, the type of 
reproduction: ovoviviparous/encysted, and the quality of the ovoviviparous offspring (living or dead nauplii together with abortive embryos or unfertilized eggs) were assessed.

\section{Statistics}

The means of the variables obtained in the life tables for the different Artemia populations have been compared through the Brown-Forsythe's test in search of differences among them, followed by the Games-Howell's test for multiple mean comparisons. Both tests are robust in cases of variance heteroscedasticity, which have been very frequent in our study due to the high dispersion that these traits show. In fact, only the mean time elapsed between broods has proved to present homogeneous variances. In addition, the variables quantified as percentage lack of the necessary normality and, consequently, it is not advisable the use of the above mentioned statistical treatment. Instead, non parametric statistics (Kruskal-Wallis' tests) have been employed to assert mean differences in these variables. Statistical analyses were performed with the SPSS 14.0 for Windows package (SPSS Inc., Chicago, IL, USA).

\section{RESULTS}

\section{Biotope loss}

The loss of hypersaline biotopes, especially the solar salterns adequate for the development of brine shrimp populations, attains $74 \%$ in Spain, $63 \%$ in Italy and about $55 \%$ in Portugal (Table 2).

\section{Invasion extent}

The widespread presence of $A$. franciscana in the Western Mediterranean region is confirmed (Table 1) after its populations identification by adult biometry (Figs. 1 and 2). This is specially remarkable almost in all the saltworks from Portugal. However, two salterns isolated from the important saltworks areas have been also visited: the Rio Maior saltern $\left(39^{\circ} 21^{\prime} \mathrm{N}-8^{\circ} 56^{\prime} \mathrm{W}\right)$, an inland saline spring close to the city of Santarem, and the Senitra saltern $\left(40^{\circ} 38^{\prime} \mathrm{N}-8^{\circ} 39^{\prime} \mathrm{W}\right)$,
Table 2. Approximate distribution of habitat loss, mainly solar salterns, in the Western Mediterranean region during the last 20 years, particularized for countries and regions. Data given as percentages. Distribución aproximada de los hábitats perdidos, principalmente salinas solares, en la región del Mediterráneo Occidental durante los últimos 20 años, particularizada por países y regiones. Los datos se dan como porcentajes.

\begin{tabular}{|lc|}
\hline SPAIN & $\mathbf{7 4}$ \\
\hline Catalonia & 50 \\
Valencia & 45 \\
Murcia & 65 \\
Aragon & 85 \\
Navarre & 100 \\
Castile-La Mancha & 80 \\
Andalusia* & 75 \\
Balearic Islands & 75 \\
Canary Islands & 85 \\
\hline ITALY & $\mathbf{6 3}$ \\
\hline Veneto & 100 \\
Apulia & 30 \\
Lazio & 100 \\
Sardinia & 60 \\
Sicily & 25 \\
\hline PORTUGAL & $\mathbf{5 5}$ \\
\hline Algarve & 25 \\
Sado Estuary & 80 \\
Tagus Estuary & 75 \\
Mondego Estuary & 20 \\
Aveiro & 50 \\
\hline *67 continental, 82 coastal & \\
\hline
\end{tabular}

close to the saltworks complex of the Aveiro district. Both salterns, with small extension and traditional exploitation, show the presence of diploid parthenogenetic strains belonging to the autochthonous populations of Artemia. These are the two only native populations found in Portugal compared to the extensive presence of $A$. franciscana, from the South (Algarve) to the North (Aveiro).

In Italy the appearance of a population of the exotic form $A$. franciscana in the Margherita di Savoia salterns $\left(41^{\circ} 22^{\prime} \mathrm{N}-16^{\circ} 5^{\prime}\right.$ E) on the Adriatic coast, in the province of Apulia (Mura et al., 2004, Mura et al., 2005a) has been recently verified. The first evidences of its introduction come from the study of a cyst sample collected 


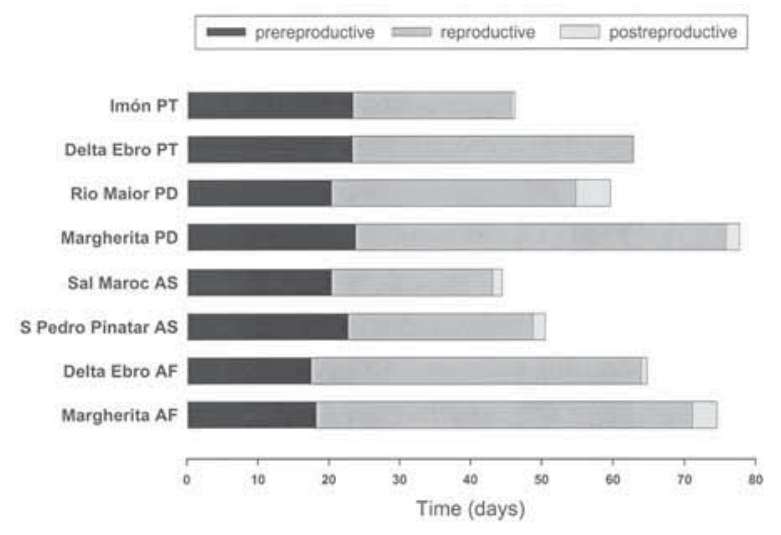

Figure 3. Time elapsed during prereproductive, reproductive and postreproductive periods, and total life span, in days, obtained from the life tables studied for populations (8) from different species and strains (4) under experimental static conditions. Duración de los períodos prereproductivo, reproductivo y postreproductivo, y de la vida total, en días, obtenida del estudio de tablas de vida para poblaciones (8) de diferentes especies y cepas (4) bajo condiciones de experimentación estáticas.

in February 2004. The population obtained in the laboratory from these cysts confirmed that the higher fraction of Artemia was autochthonous diploid parthenogenetic individuals, with a scarce presence of $A$. franciscana (1.20\% of individuals). The samples obtained during the next summer season show the dominant presence of the invasive species. Other worth mentioning localities are the Cervia salterns $\left(44^{\circ} 15^{\prime} \quad \mathrm{N}-12^{\circ} 20^{\prime}\right.$ E) in the Adriatic littoral, and Torrecolimena salterns $\left(40^{\circ} 18^{\prime} \mathrm{N}-17^{\circ} 43^{\prime} \mathrm{E}\right.$ ), in the Tarentum Gulf (Ionic Sea) (Mura et al., 2005b), housing exclusively autochthonous parthenogenetic populations.

In the important Sardinian saltern complexes of Cagliari (Molentargius and Contivecchi) and in Sant'Antioco, as well as in the Trapani-Paceco saltern complex (Maria Estela saltern) from Sicily, native A. salina (bisexual) and diploid parthenogenetic populations have been exclusively found.

In France A. franciscana is present in the saltern complexes from Sète-Aigües Mortes $\left(43^{\circ} 3^{\prime} \mathrm{N}-4^{\circ} 11^{\prime} \mathrm{E}\right)$ in the Languedoc), in the large salterns in Salin de Giraud (Etang de Vaccarés, $\left.43^{\circ} 30^{\prime} \mathrm{N}-4^{\circ} 3^{\prime} \mathrm{E}\right)$ and those in Provence. However, different diploid parthenogenetic populations have been located in hypersaline ponds in La Palme-Sigean $\left(42^{\circ} 58^{\prime}\right.$ N- $3^{\circ} 1^{\prime}$ E).

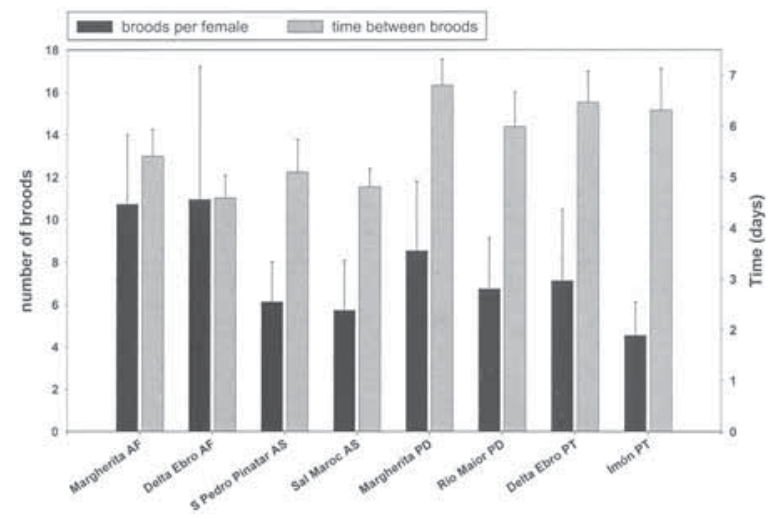

Figure 4. Total number of broods per female, and time elapsed between broods, obtained from the life tables studied for populations (8) from different species and strains (4) under experimental static conditions. Número total de puestas emitidas por hembra, y duración del período transcurrido entre puestas, obtenidos del estudio de tablas de vida para poblaciones (8) de diferentes especies y cepas (4) bajo condiciones de experimentación estáticas.

In Spain, different sampling campaigns have allowed to add to the population inventory new autochthonous populations as the diploid parthenogenetic from El Bosque in the province of Cádiz ( $\left.36^{\circ} 47^{\prime} \mathrm{N}-5^{\circ} 33^{\prime} \mathrm{W}\right)$ and the parthenogenetic tetraploid from Poza de la Sal in the province of Burgos $\left(42^{\circ} 40^{\prime} \mathrm{N}-3^{\circ} 30^{\prime} \mathrm{W}\right)$. In addition, these recent prospections have evidenced the presence of new A. franciscana introductions as in the River Ebro Delta salterns (Alfaques Bay, province of Tarragona) $\left(40^{\circ} 34^{\prime} \mathrm{N}-\right.$ $\left.0^{\circ} 40^{\prime} \mathrm{E}\right)$. Other recently invaded localities are La Tapa saltern $\left(36^{\circ} 35^{\prime} \mathrm{N}-6^{\circ} 13^{\prime} \mathrm{W}\right)$ in Puerto de Santa María (Cádiz), and Fuente de Piedra lagoon $\left(36^{\circ} 45^{\prime} \mathrm{N}-5^{\circ} 31^{\prime} \mathrm{W}\right)$ in the province of Malaga. These data support the idea that most Artemia habitats of this Atlantic area in the South of Spain and Portugal are already colonized by the exotic invasive species.

\section{Life tables}

The observation of temporal parameters obtained from life tables, as shown in figure 3, allow to confirm that $A$. franciscana females develop a prereproductive period markedly shorter (18 days) than the females from all the other autochthonous populations (20 to 30 days). Brown- 


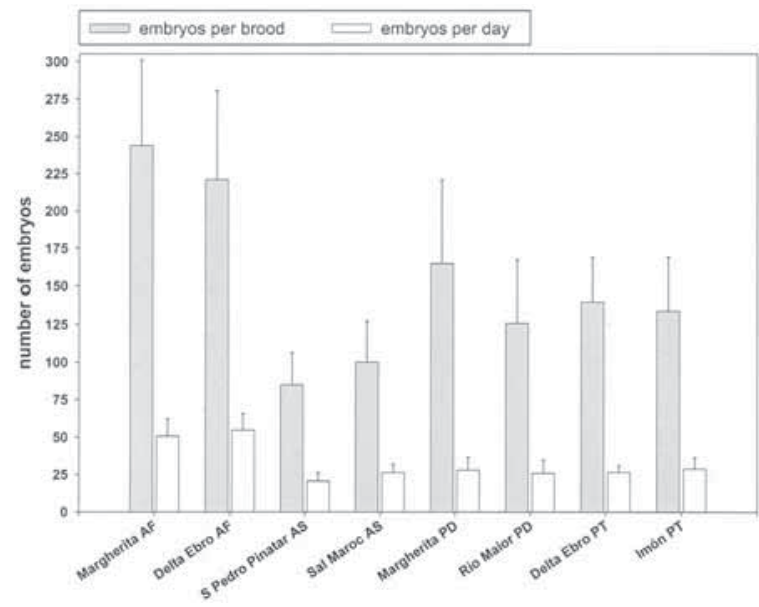

Figure 5. Fecundity in terms of embryos per brood and per day, per female, obtained from the life tables studied for populations (8) from different species and strains (4) under experimental static conditions. Fecundidad en términos de número de embriones obtenidos por puesta, por día y por hembra, obtenida del estudio de tablas de vida para poblaciones (8) de diferentes especies y cepas (4) bajo condiciones de experimentación estáticas.

Forsythe's plus Games-Howell's test show significant differences $(p \leq 0.05)$ between $A$. franciscana and all the other species for this trait.

Females from both bisexual species ( $A$. franciscana and A. salina) show a similar time period elapsed between successive broods, while this period is always longer for parthenogenetic females. The reproductive period and total life span are very similar for both $A$. franciscana and most of the diploid parthenogenetic females, as in the case of the parthenogenetic strain from Margherita di Savoia. However, this is not true for the Rio Maior strain. The postreproductive period seems to be negligible in all cases and presumably does not contribute to the assessment of the biological fitness. Total life span is markedly shorter for the females of the bisexual autochthonous A. salina populations, attaining only 40 to 50 days.

The quantitative traits for reproduction show markedly higher values in A. franciscana, especially in important outputs as the total number of broods per female (Fig. 4) and total offspring per brood and per day (Fig. 5). The exotic $A$. franciscana females show the largest va-

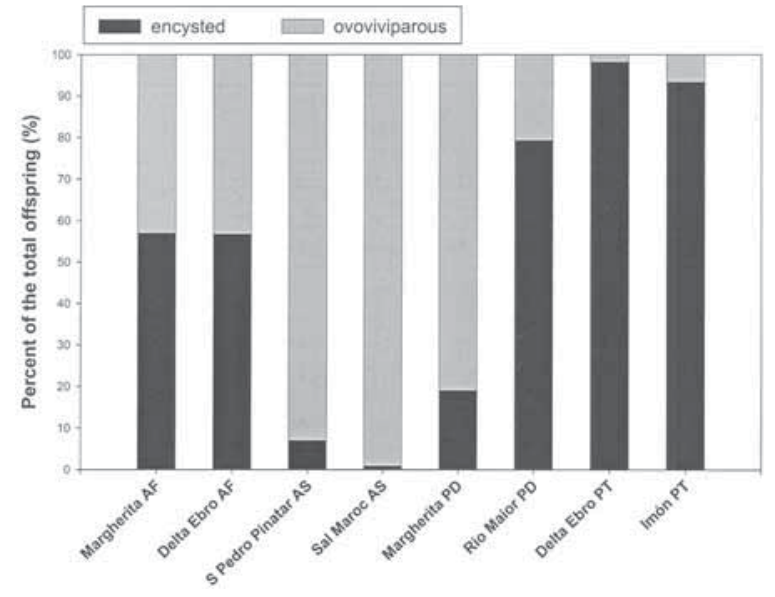

Figure 6. Qualitative reproduction in terms of percentage of the total ovoviviparous vs. encysted offspring, obtained from the life tables studied for populations (8) from different species and strains (4) under experimental static conditions. Calidad reproductiva en términos de porcentaje de puestas ovovivíparas versus ovíparas (enquistadas) sobre el total de puestas, obtenida del estudio de tablas de vida para poblaciones (8) de diferentes especies y cepas (4) bajo condiciones de experimentación estáticas.

lues for these reproductive outputs, which usually duplicate those of the autochthonous strains. Nevertheless, among the autochthonous strains, the reproductive outputs are always higher for the parthenogens, compared to those of the bisexual A. salina. Brown-Forsythe's plus Games-Howell's tests show significant differences $(p \leq 0.05)$ for time elapsed between broods and total offspring produced per day between $A$. franciscana and all the other species for both traits, being the former the shorter and the latter the bigger for the exotic species among the experimental populations, respectively.

A marked oviparism (encysted offspring) was found in the parthenogenetic strains, which is nearly exclusive in tetraploid strains (Barata et al., 1995). However, the Margherita di Savoia diploid parthenogenetic females are an exception in this case. In opposition to parthenogens, the bisexual $A$. salina females display scarce oviparism, while $A$. franciscana females show a substantial balance between oviparism $(57 \%$. Fig. 6) and ovoviviparism.

Some remarks dealing with the quality of ovoviviparous offspring, usually not considered 


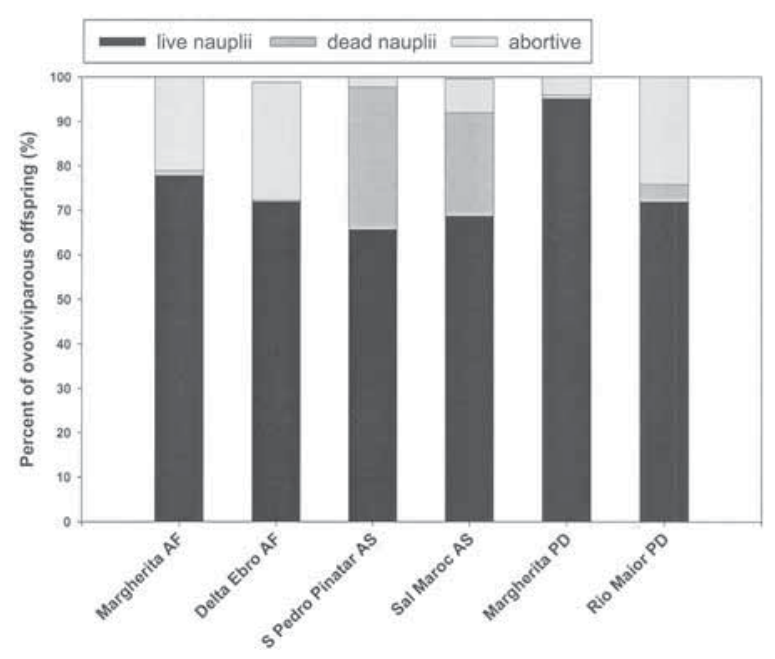

Figure 7. Differences in qualitative ovoviviparous offspring in diploid (bisexual and parthenogentic) species and strains, with expression of relative percentages of live and dead nauplii, and abortive embryos, obtained from the life tables studied for populations (8) from different species and strains (4) under experimental static conditions. Diferencias cualitativas halladas en la descendencia ovovivípara de especies y cepas diploides (bisexuales y partenogenéticas), especificando los porcentajes relativos de nauplios vivos, muertos y de embriones abortivos, obtenidas del estudio de tablas de vida para poblaciones (8) de diferentes especies y cepas (4) bajo condiciones de experimentación estáticas.

in the literature available are worth to mention. Ovoviviparous broods tipically comprise living and dead nauplii, together with abortive embryos showing arrested development. Sometimes they are remnant ovocites not properly fertilized by males in bisexual species. The quality of these ovoviviparous outputs should be considered when estimating the reproductive and invasive success. In this work it has been possible to discern the presence of $20 \%$ to $30 \%$ of the ovoviviparous offspring as abortive in the two $A$. franciscana populations studied. While similar percentages of dead nauplii are present in the autochthonous bisexual $A$. salina, the diploid parthenogenetic strain from Margherita di Savoia displays a high level of ovoviviparous quality attaining the $95 \%$ of the ovoviviparous output as living nauplii (Fig. 7). An exception to this is the case of the Rio Maior population, which shows a living nauplii proportion of about $75 \%$ of the ovoviviparous progeny, together with a marked tendency for encysted offspring.

\section{DISCUSSION}

We report evidences of the dramatic loss of hypersaline habitats in the Mediterranean basin. In Spain one of the most accurate and strict inventories was performed in the Andalusian Region, where 36 solar salterns are today in exploitation out of the 185 accounted for two or three decades ago. It is also surprising the fact that the remaining are mostly inland $(33 \%)$ with fewer littoral salterns remaining active $(18 \%)$. The perdurability and fate of these small and traditionally managed inland exploitations is threatened by scarce rentability and returns. The littoral small exploitations are affected by the same threats, but also by the pressure to switch to more productive activities like intensive fish culture or urban projects for tourism and leisure.

Something similar is happening in Portugal and Italy. Portuguese salterns in the estuary of the Sado River switched to rice fields, while fish culture is developed massively in the estuary of the Tagos River. Some peninsular salterns in Italy were abandoned after recent floods (Comacchio in the Venetian region, Tarquinia in the Lazio), while most Eastern Sicilian salterns switched to agriculture (Pachino-Marzameni).

The previous report by Amat et al., (2005) stated the widespread presence of $A$. franciscana in the hypersaline ecosystems from Portugal. This presence could have started in the decade of 1980 (Hontoria et al., 1987), when it was observed for the first time in the southern salterns, in the district of Algarve. At that time, A. franciscana was not present in the northern Portuguese regions, in the district of Aveiro (Vieira \& Amat, 1985), and it has been likely progressing from South to North.

The time and place of the original introduction of the exotic species in Portugal is completely unknown, and could have been a human decision (aquaculture), but from that moment the presumable dispersion via water birds begun along the East Atlantic flyway, West of Gibraltar (Green et al., 2005). This hypothesis could be confirmed after verifying the taxonomic adscription of the bisexual Artemia populations that presently thrive in La Guerande salterns (South of Bretagne, 
France) (Joseph Baudet, personal communication, 2005). The presence of parthenogenetic tetraploid brine shrimp populations in these localities (Amat, 1983) has been known from the end of the 1970's decade. If present populations are bisexual, it is hard to believe that they belong to the Mediterranean bisexual A. salina, unsuitable for these northern latitudes.

A similar dispersive phenomenon related to the existence of the West Mediterranean flyway, East of Gibraltar (Green et al., 2005), favoring an Artemia dispersion via water birds is still uncertain. Nevertheless, the massive presence of $A$. franciscana in most of the active salterns in Cádiz Bay is well known (Amat et al., 2005). More pieces of evidence pointing towards this hypothesis come from the recent (2005) findings of $A$. franciscana in the exploited La Tapa salterns (Puerto de Santa María, Cádiz) and in the Fuente de Piedra (Málaga) inland hypersaline lagoon, the most important nesting area for flamingos in the Iberian Peninsula, and where authors are not aware of any introduction by humans.

The presence of $A$. franciscana in the Ebro Delta salterns (Alfaques Bay, Tarragona) (Figs. 1 and 2), as well as in the French salterns in Sète and Aigües Mortes (Languedoc-Roussillon) (Thiéry \& Robert, 1992; Amat et al., 2005) could support the suspected role of water birds as dispersors of $A$. franciscana through their West Mediterranean flyway, probably also reaching the Italian salterns in Margherita di Savoia (Apulia) in the Adriatic Sea (Mura et al., 2004). In any case, the massive inoculation of the exotic species in important industrial salterns in the Mediterranean basin must not to be dismissed.

These hypothetical inoculations (antropic pressure), together with the presence of water birds in marine solar salterns as breeding and wintering sites, increase the probabilities for dispersion of the exotic invasive A. franciscana. However, the presence of autochthonous brine shrimp species and strains in small inland salterns, and in isolated sea shore salterns, like Rio Maior (Santarem) and Senitra (Aveiro) in Portugal; El Bosque (Cádiz), Añana (Alava), Poza de la Sal (Burgos) in Spain, or Torrecolimena (Apulia), Molentargius (Sardinia),
Trapani (Sicily) in Italy, offer some hope for the maintenance of Artemia biodiversity in the Western Mediterranean. However, these small ecosystems are also threatened of abandonment by lack of economical interest, and so is the Artemia biodiversity.

Some Mediterranean countries are developing interesting projects to repair solar salt exploitations, old sites witnessing important cultural, ethnographic and historical roots. This is the case for Añana (Alava), Poza de la Sal (Burgos), Imón (Guadalajara), in Spain, similarly to the Ettore-Infersa salt complex (Marsala-Trapani) in Sicily (Italy), or Rio Maior in Portugal. In all these small inland and marine salterns it is possible to find the suitable conditions for the persistence of the autochthonous Artemia species and strains ( $A$. salina and parthenogenetic forms). These sites are out of the main water bird flyways, although they are not free of the antropic intervention in terms of exotic species inoculations or an accidental introduction by the small number of birds that visit the area. This has already happened in Gerri de la Sal (Baix Pallars, Lleida) salterns, where the introduction of A. franciscana in the last decades of the twentieth century eliminated the autochthonous diploid parthenogenetic strain.

Environmental factors like salinity, temperature, food or oxygen availability, or factors related to the population dynamics, like the different species cooccurrence, crowding, type of reproduction, rule the response of different populations in terms of biological fitness and life span (Browne $e t$ al., 1984, 1988, 1991; Barata et al., 1995, 1996a,b). Among these traits, the length of prereproductive and reproductive periods has the most important effect on organismal fitness (Allan, 1976).

The biological fitness assessed in this research was developed in static conditions, according to criteria supported by Browne (1980) and Browne \& Halanych (1989), enabling to build up comparative and competing results for bisexual A. salina and $A$. franciscana species, as well as for parthenogentic strains. Several authors have evaluated the combined effects of salinity and temperature on biological fitness for diverse populations of these strains and species (Browne et al., 1988, Browne \& Wanigasekera, 2000; Barata et al., 1996b). In all cases it has been 
stated that the Mediterranean bisexual A. salina is the less tolerant to high temperatures. The responses in terms of biological fitness (longer life span) associated to higher temperatures are in favor of the exotic species A. franciscana, even with a broader tolerance than that of the parthenogenetic strains.

The autochthonous Artemia species and parthenogenetic strains present adaptive and tolerance mechanisms to well defined ranges of environmental changes. The bisexual A. salina prefers low temperatures but does not perform properly at salinities lower than $60 \mathrm{~g} \mathrm{~L}^{-1}$ (Amat, 1983; Barata et al., 1996b; Browne \& Wanigasekera, 2000). In the Mediterranean basin the bisexual and the diploid parthenogenetic populations can coexist in the same saltern. Usually there are conditions favorable to A. salina early in the year at lower temperatures and salinities, with a later seasonal dominance for parthenogens at higher temperatures and salinities. Barata et al., (1996a) reported the competitive displacement of $A$. salina by parthenogenetic strains at $24^{\circ} \mathrm{C}$, while the former performs better than the parthenogenetic at $15-20^{\circ} \mathrm{C}$.

Our results are in agreement with the above generalizations. The exotic A. franciscana populations introduced in Margherita di Savoia and River Ebro Delta display the longest reproductive periods studied. The diploid parthenogenetic strain from Margherita di Savoia shows a similar reproductive period length (50 days). In addition, the exotic species shows shorter prereproductive and between brood periods. When autochthonous strains release their first brood, the exotic species has already produced two offspring batches. If these are ovoviviparous nauplii, their presence trigger the competitive superiority developed by A. franciscana in terms of total offspring per batch, per day and per female. It is possible to observe (Figs. 3 to 7) the regularity in offspring production developed by the A. franciscana populations studied, with a twofold offspring output per female and per day in comparison with the autochthonous strains. The significant differences found between both $A$. franciscana populations and all the other species populations for those three basic fitness traits (prereproductive and between brood periods, together with offspring output per female and per day) support the competitive superiority developed by the exotic invasive species, what has been observed recently in competitive studies in open air microcosm in progress.

According to Browne et al., (1984) and Lenz \& Browne (1991) the greatest differences in reproductive output, in terms of fecundity and offspring quality, are found between the bisexual species A. franciscana from the American continent and the Mediterranean A. salina. Sometimes these differences are not so clear between the bisexual American species and the Old World diploid parthenogenetic strains, although $A$. franciscana females display the greatest fecundity of all, as stated in this work.

There is a powerful argument that can be presented to explain the failure of the putative superiority in some bisexual species on the basis of their reproductive output. Mediterranean $A$. salina is a clear example. Bisexuals must pay for the meiosis cost. Females need to be fertilized by sexual males. Bisexual offspring production needs the presence of the two sexes, which is irrelevant for parthenogens.

The tetraploid parthenogenetic females display low fecundity, although their bigger size and biomass could be linked to higher fecundities (Zhang \& King, 1993). This lower offspring production is also more remarkable due to the dominance of oviparism (encysted offspring), a more costly reproductive mode than ovoviviparism, because $22 \%$ of the dry mass of a cyst batch is utilized for encapsulation (Clegg, 1962; Von Hentig, 1971, in Barata et al., 1995). This is true even when there is some level of ovoviviparism, producing embryos and nauplii of bigger size than the other diploid species or strains, due to the polyploidy. Polyploid Artemia strains are usually spread in continental, as well as in high latitudinal, hypersaline environments, although they have been recently found in solar salterns in Northern Africa (Morocco, Algeria, and Tunisia). This distribution and type of reproduction, bound to some quality of "robustness" associated to polyploids and colonizing strains, is also linked to an adaptation to flourish during the short length of the inhabitable period of 
their inland uncertain environments (Browne et al., 1984, 1988; Barata et al., 1995).

A few decades ago the exotic species A. franciscana appeared into the Mediterranean landscape. In addition to better performances in biological fitness, the exotic species displays wider eurythermal and euryhaline capabilities (Browne \& Wanigasekera, 2000). These are advantages characterizing a "super species" spread unrestrictedly along the American continent. The only exception is the Patagonian region in the American South Cone, where A. persimilis is still enduring a hypothetical invasion by $A$. franciscana from the North (Amat et al., 2004). The superspecies, endowed with high levels of phenotypic plasticity (Abatzopoulos et al., 2002), becomes an invasive species in Asia, Africa and Europe, where outcompetes the autochthonous species, which are laid aside and eliminated in all cases. This situation agrees completely with laboratory experimental results, where diverse organisms, different from the brine shrimp, display practical exclusion among congeneric species into 10 to 100 generations (Miller, 1967), but in the case of Artemia, according to Lenz \& Browne (1991), and our own unpublished results, exclusion may be attained after only 2 to 3 generations.

The displacement or elimination of most autochthonous populations in our latitudes is evident in Portugal and France, and runs progressively in continental Spain and Italy. This is in progress not only in the Western Mediterranean, but it is being reported also in the Middle and Far East, i.e. in Iraq, India, Pakistan, China, countries where autochthonous species existed before. Massive introductions are only conceivable through antropic intervention, and probably this is the only way to explain its fast progression in sites like Margherita di Savoia (Italy). In a similar way it is possible to explain the present situation in the salterns of the Hebei province in China (Tanggu, Luanan, Dagang, from own unpublished results) where, in the last five to ten years, autochthonous bisexual $A$. sinica and diploid parthenogenetic populations have been practically eradicated, changing to a nearly exclusive predominance of the exotic invasive A. franciscana.
Once these sites of massive introduction have been established, a broad dispersion East and Westwards in the Old World, at short and middle term, is warranted through the cyst exchange performed among salt exploitations and aquacultural development. Together with the unavoidable dispersion via migrating water birds, a long term important loss of Artemia biodiversity into natural environments is conceivable. Only exceptionally isolated hypersaline ecosystems could harbour autochthonous strains, not completely free from threatening introductions, similarly to what is happening in the Western Mediterranean.

In the present situation it is difficult to anticipate any particular measure to prevent or eradicate the exotic brine shrimp species, similarly to what usually is applied to invaders. The oviparism mode of reproduction warrants the persistence of Artemia in any invaded or colonized ecosystem. Otherwise, a possible way to attain a circumstantial suppression of the living populations of an invader species could be some kind of "biological fight" avoiding any damage to the environment itself. This biological fight could consist, for example, on massive introductions of the invader species adequately sterilized (ionic irradiations, xenobiotics), together with massive reinoculations of the autochthonous species. In any case, further scientific research on these proposals is necessary, provided their understanding and support by social, political and economical authorities.

\section{ACKNOWLEDGEMENTS}

This work was supported by the Spanish National Plan R+D projects CGL2004-03719 and CGL2005-02306, together with the international Concerted Actions HP2002-0051 and HI20020113 between Spain, Portugal and Italy.

\section{REFERENCES}

ABATZOPOULOS, T. J., J. A.BEARDMORE, J. S. CLEGG \& P. SORGELOOS. 2002. Artemia: Basic and applied biology. Kluwer Academic 
Publishers, Dordrecht, The Netherlands. 286 pp.

ALLAN, J. D. 1976. Life history patterns in zooplankton. American Naturalist, 110: 165-180.

AMAT, F. 1983. Diferenciación y distribución de las poblaciones de Artemia de España, VI. Biogeografía. Investigación Pesquera, 47(2): 231240.

AMAT, F., C. BARATA, F. HONTORIA, J. C. NAVARRO \& I. VARO. 1995. Biogeography of the genus Artemia (Crustacea, Branchiopoda, Anostraca) in Spain. International Journal of Salt Lake Research, 3 (2): 175-190.

AMAT, F., R. G. COHEN, F. HONTORIA \& J. C. NAVARRO. 2004. Further evidence and characterization of Artemia franciscana (Kellogg, 1906) populations in Argentina. Journal of Biogeography, 31: 1735-1749.

AMAT, F., F. HONTORIA, O. RUIZ, A., J. GREEN, M. I. SANCHEZ, J. FIGUEROLA \& F. HORTAS. 2005. The American brine shrimp as an exotic invasive species in the western Mediterranean. Biological Invasions, 7: 37-47.

BARATA, C., F. HONTORIA \& F. AMAT. 1995. Life history, resting egg formation, and hatching may explain the temporal-geographical distribution of Artemia strains in the Mediterranean basin. Hydrobiologia, 298: 295-305.

BARATA, C., F. HONTORIA, F. AMAT \& R. BROWNE. 1996 a. Competition between sexual and parthenogenetic Artemia: temperature and strain effects. Journal of Experimental Marine Biology and Ecology, 196: 313-328.

BARATA, C., F. HONTORIA, F. AMAT \& R. BROWNE. 1996 b. Demographic parameters of sexual and parthenogenetic Artemia: temperature and strain effects. Journal of Experimental Marine Biology and Ecology, 196: 329-340.

BROWN, R. A. 1980. Competition experiments between parthenogenetic and asexual strains of the brine shrimp, Artemia salina. Ecology, 61: 471474.

BROWNE, R. A., S. E. SALLEE, D. S. GROSCH, W. O. SEGRETI \& S. M. PURSER. 1984. Partitioning genetic and environmental components of reproduction and lifespan in Artemia. Ecology, 65: 949-960.

BROWNE, R. A., L. E. DAVIS \& S. E. SALLEE. 1988. Effects of temperature and relative fitness of sexual and asexual brine shrimp Artemia. Journal of Experimental Marine Biology and Ecology, 124: 1-20.
BROWNE, R. A. \& K. M. HALANYCH. 1989. Competition between sexual and parthenogenetic Artemia: a re-evaluation. Crustaceana, 51: 59-69.

BROWNE, R. A., G. WANIGASEKERA, S. SOMONEK, D. BROWNLEE, G. EIBAND \& J. COWAN. 1991. Ecological, physiological and genetic divergence of sexual and asexual (diploid and polyploidy) brine shrimp Artemia. Advances in Ecology, 1: 41-52.

BROWNE, R. A. \& G. WANIGASEKERA. 2000. Combined effects of salinity and temperature on survival and reproduction of five species of Artemia. Journal of Experimental Marine Biology and Ecology, 244: 29-44.

BYERS, J. E. 2000. Competition between two estuarine snails: implications for invasions of exotic species. Ecology, 81 (5): 1225-1239.

CLEGG, J. S. 1962. Free glycerol in dormant cysts of the brine shrimp Artemia salina, and its disappearance during development. Biological Bulletin, 123: 295-301.

COHEN, R. G., F. AMAT, F. HONTORIA \& J. C. NAVARRO. 1999. Preliminary characterization of some Argentinean populations of the brine shrimp Artemia (Crustacea, Branchiopoda, Anostraca). Provinces of La Pampa and Buenos Aires. Int. Journal of Salt Lake Res, 8: 329-340.

EHRLICH, P. R. 1984. Which animal will invade?. In: Ecology of Biological Invasions of North America and Hawaii. H. A. Mooney \& J. A. Drake (eds.): 79-95. Springer-Verlag, New York.

ELTON, C. S. 1958. The Ecology of Invasions by Animals and Plants. London: Methuen. 181 pp.

FRONTERA, M. 2005. Salines de Les Balears. Fundació "Sa Nostra”, Caixa Balears, Palma de Mallorca. 202 pp.

GAJARDO, G., J. CRESPO, A. TRIANTAPHYLLIDIS, A. TZIKA, A. D. BAXEVANIS, I. KAPPAS \& T. J. ABATZOPOULOS. 2004. Species identification of Chilean Artemia populations based on mitochondrial DNA RFLP analysis. Journal of Biogeography, 31: 547-555.

GREEN, A. J., M. I. SÁNCHEZ, F. AMAT, J. FIGUEROLA, F. HONTORIA, \& F. HORTAS. 2005. Dispersal of invasive and native brine shrimp Artemia (Anostraca) via waterbirds. Limnol. Oceanogr., 50: 737-742.

GROSHOLZ, E. E. \& G. M. RUIZ. 1996. Predicting the impact of introduced marine species: lessons from the multiple invasions of the European green 
crab Carcinus maenas. Biological Conservation, 78:59-66.

HERBOLD, B. \& P. MOYLE. 1986. Introduced species and vacant niches. Am. Nat., 125: 751-760.

HONTORIA, F., J. C. NAVARRO, I. VARO, A. GOZALBO, F. AMAT y N. VIEIRA. 1987. Ensayo de caracterización de cepas autóctonas de Artemia de Portugal. Seminario Aquac. Inst. Ciencias Biom. "Abel Salazar" Porto (Portugal). Publ. Inst. C. Biomed. 10 pp.

HONTORIA, F. \& F. AMAT. 1992 a. Morphological characterization of adult Artemia (Crustacea, Branchiopoda) from different geographical origin. Mediterranean populations. J. Plankton Res., 14 (7): 949-959.

HONTORIA, F. \& F. AMAT. 1992 b. Morphological characterization of adult Artemia (Crustacea, Branchiopoda) from different geograpghical origin. American populations. J. Plankton Res., 14 (10): 1461-1471.

JIMENEZ PEREZ, I. 2005. ¿Qué sabemos sobre los factores que afectan al proceso de recuperación de la fauna amenazada? In: Al borde de la Extinción. I. Jiménez Perez y M. Delibes de Castro (eds.): 2945. EVREN. Valencia. España. 442 pp.

LENZ, P. H. \& R. A. BROWNE.1991. Ecology of Artemia. In: Artemia Biology. R. A. Browne, P. Sorgeloos \& C. N. Trotman (eds.): 237-253 CRC Press, Boca Raton, Florida.

LODGE, D. M. 1993. Biological Invasions: lessons for ecology. Trends in Ecology and Evolution, 8: 133-137.

MARIN, C. y A. LUENGO. 1994. El Jardin de la Sal. C. Marín y A. Luengo (eds.). Cabildo Insular de Lanzarote. 247 pp.

McMAHON, R. F. 2002. Evolutionary and physiological adaptations of aquatic invasive animals: $r$ selection versus resistance. Can. J. Fish Aquat. Sci., 59: 1235-1244.

MILLE, R. S. 1967. Patterns and process in competiton. Advances in Ecology Research, 4: 1.

MOONEY, H. A. \& E. E. CLELAND. 2001. The evolutionary impact of invasive species. Proc. Nat. Acad. Sci., USA. 98: 5446-5451.

MURA, G., F. AMAT, T. J. ABATZOPOULOS \& S. MOSCATELLO. 2004. First record of Artemia franciscana in an Italian saltwork. Book of abstracts. 35-36. Fifth International Large Branchiopod Symposium. Toodyay. August 2004. Western Australia.
MURA, G., I. KAPPAS, A. D. BAXEVANIS, S. MOSCATELLO. S, Q. D'AMICO, G. MEDINA, F. HONTORIA, F. AMAT \& T. J. ABATZOPOULOS. Morphological and molecular data reveal the presence of the invasive Artemia franciscana in Margherita di Savoia. Intern. Rev. Hydrobiol., 91: 539-544.

MURA, G., A. D. BAXEVANIS, G. MEDINA, F. HONTORIA, I. KAPPAS, S. MOSCATELLO, G. FANCELLO, F. AMAT \& T. J. ABATZOPOULOS. 2005. The use of a multidisciplinary approach for the characterization of a diploid parthenogenetic Artemia population from Torre Colimena (Apulia, Italy). J. Plankton Res., 27 (9): 895-907.

PEREZ HURTADO DE MENDOZA, A. 2004. Salinas de Andalucía. Consejería de Medio Ambiente, Junta de Andalucía y Universidad de Cádiz, Sevilla. 302 pp.

SAKAI, A. K., F. W. ALLENDORF, J. S. HOLT, D. M. LODGE, J. MOLOFSKY, K. A. WITH, S. BAUGHMAN, R. J. CABIN, J. E. COHEN, N. C. ELLSTRAND, D. E. MCCAULEY, P. O’NEIL, I. M. PARKER, J. N. THOMPSON \& S. G. WELLER. 2001. The population biology of invasive species. Ann. Revue Ecol. Syst., 32: 305-332.

SHIGESADA, N. \& K. KAWASAKI. 1997. Biological Invasions: Theory and Practice. London: Oxford University Press. 205 pp.

SIMBERLOFF, D. 1996. Impacts of introduced species in the United States. Consequences. Natural Implications Environmental Change, 2: 13-22.

THIERY, A. \& F. ROBERT. 1992. Bisexual populations of the brine shrimp Artemia in Sète-Villeroy and Villeneuve saltworks (Languedoc, France). International Journal of Salt Lake Research, 1: 4763.

TRIANTAPHYLLIDIS, G. V., T. J. ABATZOPOULOS \& P. SORGELOOS. 1998. Review of the biogeography of the genus Artemia (Crustacea, Anostraca). Journal of Biogeography, 25: 213-226.

VANHAECKE, P. \& P. SORGELOOS. 1980. International Study on Artemia. IV. The biometrics of Artemia strains from different geographical origin. In: The Brine Shrimp Artemia, G. Persoone, P. Sorgeloos, R. Roels \& E. Jaspers (eds.), pp: 393405. Universa Press, Wetteren, Belgium.

VANHAECKE, P., W. TACKAERT \& P. SORGELOOS.1987. The biogeography of Artemia: an updated review. In: Artemia Research and its 
Applications, P. Sorgeloos, D. A. Bengtson, W. Decleir \& E. Jaspers (eds.).Vol. 1: 129-155, Universa Press, Wetteren, Belgium.

VIEIRA, M. N. \& F. AMAT. 1985. Artemia sp. from Aveiro: its characterization. Publicaçoes do Instituto de Zoologia "Dr. Augusto Nobre”. Faculdade de Ciencias do Porto, 191: 1-9.

VON HENTIG, R. 1971. Einfluss von Salzgehalt und Temperatur auf Entwicklung, Wachstum,
Fortpflanzung und Energiebilanz von Artemia salina. Marine Biology, 9: 145-182.

WOOTON, J. T. 1994. The nature and consequences of indirect effects in ecological communities. Ann. Rev. Ecol. Syst., 25: 433-466.

ZHANG, L. \& C. E. KING. 1993. Life history divergence on sympatric diploid and polyploidy populations of brine shrimp Artemia parthenogenetica. Oecologia (Berlin), 93: 177-182. 